\title{
THE EFFECT OF APPLYING PLANTED QUESTION ON STUDENTS'ACHIEVEMENT IN WRITING NARRATIVE TEXT OF NINETH GRADE OF SMP PABAKU STABAT
}

\author{
Fredy Wilamenggi ${ }^{1}$, Conny, M. Hum ${ }^{2}$ \\ STKIP BUDIDAYA BINJAI
}

\begin{abstract}
The study is concerning with experimental study which discussed the effect of planted question technique on students' achievement in writing narrative text. It took place at SMP Pabaku Stabat. The subjects were the nineth grade students with the population of 132 students. 60 students were chosen as the sample and group into experimental and control group. Each group consisted of 30 students. The experimental group was taught with planted question technique while the control one was taught without planted question technique. A writing test was used to collect the data on the students' writing ability. The data collected were analyzed by using t-test. The result of the data analysis showed that the t-observed was 6,53 . It was higher that the value of $\mathrm{t}$-table $\left(\mathrm{t}_{\mathrm{t}}\right.$ is 1,67 for $5 \%$ and 2,39 for $1 \%$. This meant that the alternative hypothesis (Ha) was accepted. It can be concluded that there is effect of planted question technique on students' achievement in writing narrative text of nineth grade of SMP Pabaku Stabat.
\end{abstract}

\section{Keyword: Writing, Narrative text, Planted Question Technique}

\section{INTRODUCTION}

English is an international language which is widely used in many countries around the world. It is very important for students to master English in all skills. The skills are Listening, Speaking, Reading, and Writing. Those skills are related to each other. In this case, the researcher is going to focus on writing skill. Writing is a language skill that is very important.

The first significance of writing is that writing is the top level of a language. It is the last macro skill that must be mastered by people who want to be able to communicate perfectly. The second significance is that writing is a productive skill. It involves producing language rather than receiving it. In writing, people will produce written language. The third significance of writing is that writing is the most complex macro skill in language mastery. In writing, people apply everything that they have got in the three stages before. or the last significance of writing is that writing is the stage of language mastery where people can generate ideas. In writing, people should construct the idea perfectly to make it so understandable that other people can catch the meaning or the purpose of the message (idea) in writing.

Students in senior high school should be able to write or produce narrative text. It is not something attractive and fun for them to write narrative text although narrative text has purpose to entertain the reader. They know many stories related to narrative text but when they have to produce their own narrative text, face many difficulties. Many students cannot get and generate their own idea. Some students have idea but cannot express it in their own 
sentences. They also have difficulties in arranging the idea into good order to form a good narrative text. they want to write.

The teacher usually asks the students to write sentence as many as they can, but they do need to know how to make their students write as many as they can. This fact encourages the research to their writing ability. Writing narrative text requires more attention in detail. There are complex rules in writing that cannot be ignored. When students write something, they have to pay more attention in word spelling dictions, grammar, purpose of their writing, and idea of their writing itself. However, the researcher finds that it is difficult for students to generate narrative text based on their idea. They are confused about how they will write their idea and arrange it into good narrative text. It happens because usually they are only given examples of narrative text. After that they should write or produce their own narrative text with limited guidance. It is the main problem that the researcher wants to try to solve by conducting this research.

Regardless of the obstructions found by students, writing is a very important competence. It is because nowadays people, who take technology as their means of communication, seem to be impossible to be separated from the activity of writing.The importance of writing is also seen from the fact that the skill has become a need for people to compete in the global era. Students need to prepare themselves for their future. They need to be able to write an application letter when applying for a job and many other kinds of written texts when doing their job after. In addition, writing is a means of expressing ideas or communicating with others. There are situations in which the ability of writing is crucial or written language is a need, as it is said that writing is needed to communicate with others who are removed in time and space, or is used for those occasions on which a permanent or semi-permanent record is required. Such situations can be easily found in their life everyday, for instance, when someone was visiting a friend but he could not meet and he left a note. Based on the issues above, the researcher offers to apply Planted question technique when teaching students in writing narrative texts. By using this kind of technique, students will consider that is easier to write or produce narrative text. Planted question technique contains the combination of speaking skills and writing skills. They also will learn how to work together with their friends in a group. It will guide students to explore and to generate their own narrative text. They will not be confused about how they will produce their own narrative text.

Planted Questions is one of the active learning methods through engineering questions given to selected learners. The Planted Questions are one of the active learning strategies that teachers use best in classroom learning. This method can help teachers to present information in the form of responses to questions that have been implanted or given prior to certain learners. In addition, this learning strategy can help learners who never ask or never even speak during the lesson hours to increase their confidence by being questioners. According to Suprijono the steps in the active method of Planted Questions are as follows: a. Teachers choose questions that will lead to the subject matter to be presented. Teachers write three to six questions and sort the questions logically. b. The teacher writes each question on a piece of paper $(10 \times 15 \mathrm{~cm})$ and writes a gesture that will be used to indicate when the questions are asked. Useful 
signs include: 1) Scratching or rubbing the nose. 2) Opening the glasses. 3) Hiding the radius. 4) And others. c. The teacher opens the Q \& A session by mentioning the topics to be discussed. Before the lesson begins, the teacher selects the learner who will ask the question. The teacher gives each paperand explain the instructions. The teacher also assures that the questions are not known to other learners. The teacher discusses and gives the first gesture. Then answer the first question, then continue with the next signs and questions.e. Then the teacher opens the forum for new questions (not the ones previously planted).

Suprijono outlined four phases in Planted Question:

\section{Preparation (Warm-up)}

The topic is introduced, and key vocabulary is addressed. This can be done using a variety of techniques: an open class discussion, group brainstorming, question and answer elicitation, predicting text content from pictures or vocabulary. The important thing is that learners are engaged with the topic and hopefully interested in it.

2. Dictation

Suprijono recommends that learners should listen to the dictation twice and that both readings should be, as far as possible, identical. The text is read at natural speed with short pauses between each sentence. Students are told not to write anything the first time, 'but allow the words to wash over them. This is to allow students to get an overall feel for the passage. On the second listening students should take do own notes at this stage the teacher should suggest that learners focus on noticing and recording key content or information words.

\section{Reconstruction}

Learners work together in small groups to reconstruct a version of the text from their shared notes. It helps if each group has a 'scribe' through whom all suggestions are channeled. The scribe writes down the group's text as it emerges from group discussion. When it is complete, the group checks the text of grammar, textual cohesion, and logical sense.

4. Analysis and correction

Learners analyze and compare their text with there constructions of other groups. In this way errors are exposed and discussed. The class may discuss the differences in the texts, then compare their texts with the original and note or make necessary corrections. Ideally, the original text should not be seen by learners until after their own versions have been analyzed.

Writing is among the most important skills that foreign language students need to develop. It is the last stage in learning language after listening, speaking, and listening. In other words, the researcher can say indicator whether students have gained all skills before or have not. Before the students must write, they should be able to listen, to speak, and to read. Writing skill differs from other skills like speaking and listening. Brown states that trends in teaching writing of ESL and other foreign languages are integrated with teaching other skills, particularly listening and speaking.

For example, when students are asked by their teachers to write related to certain topic, they may collect information from a radio, a television, magazines, internet, and directly communicating with experts of related topic. After they get enough information, they can start writing. When collecting the information, they are using listening, speaking, and reading skills. Therefore, nobody can master this ability easily and directly. Writing is not a natural skill. 
Writing belongs to productive skill rather than perceptive one. It produces a message to communicate. Spratt, Pulverness, and Williams state that writing and speaking belong to productive skills. She said that's peaking and writing, particularly, involve producing language rather than receiving it. It means that writing and speaking will produce an output as an indicator that students have learn both those skills. It is clearly that the output of speaking skill can be oral conversation or drama. Meanwhile, the output of writing skill can be written stories, letters, or other text types.

Another linguist explains that writing is a way to share personal meanings. The people construct their own views on topic. They will share their views on a topic to each other then. A person's views may be different from other people's views. It depends on their belief. Therefore, when constructing their views (ideas), the people must make it understandable and acceptable.

Writing is very significant for students in term that they should take notes from their teacher, make a report, and finish assignments from the teacher. It can be also an indicator to show that they have gained the information. It is significant for students to master writing skill the researcher. If they do not master it, it will be difficult for them to share their teacher or their friends anything in a written form.

In writing students cannot only focus on their final output (their writing). They should pay attention to the processes or steps in writing to produce a good writing. A good writing means good in terms of language, content, purpose, and referred reader. Hyland illustrates the stages of writing to give students clear understanding that writing process is significant to produce a good writing. The first stage is selection of topic. It can be done by both students and teachers. Students can find their own topic or with teachers' help. Another way, teachers can decide the topic students should use to write. The next stage is prewriting. In this case, students are involved in brainstorming, collecting data, note-taking, and outlining. The third stage is composing. Composing is another term of drafting. In this stage, students begin to write their ideas down on paper. After having composing, the next step is response to revisions. It can be conducted by teachers or peers. It is about responding to ideas, organization of text, and text style. After students are sure with their ideas, organization of text, and text style, they will step on proofreading and editing. In this stage, there will be checking and correcting form, evidence, layout, and soon.

When the stage of proofreading and editing has been carried out, it means that students have finished their writing. It is the time to step on the seventh stage, which is evaluation. In this case, teachers judge the progress students achieve within the process. Students should perform their progress by time. After teachers finish evaluating students' writing, the next step to do is publishing. It means allowing people or the writing as the finished product. It can be presenting in class how in go notice boards, or even in website.

The ninth or the last stage is having follow-up tasks. It is conducted to conclude the weaknesses of students writing. By holding this stage, latter, students are hoped to have better writing.

In another book that is related to steps of writing, Harmer offers simpler process of writing. It consists of four stages. There will be planning, drafting, editing, and final draft. 
Harmer states that students should pay attention not only in what to write but also in how to write. Writing is more than to write. There are several strategies to write well. Students are led to know more about how to write. Therefore, he offers some writing strategies in this case: The authors of this book provide scenarios about various aspects of teaching writing. Each of the scenarios highlights a specific problem or set of problems that emerges in composition courses, focusing on both theoretical issues and practical applications. They are meant to provoke discussion; each scenario is followed by a set of discussion questions. The authors envision this book as a catalyst for discussion in graduate teaching seminars, workshops, and teacher training programs. The scenarios are organized into six sections: 1) creating effective writing assignments; 2) using reading in writing courses; 3) responding to student writing; 4) teaching grammar and style; 5) managing discourse in classes, conferences, and small groups; and 6) course designs. Although the situations have been modified, the scenarios are all "real and current" (x). They have been collected from actual events and, therefore, deal with common (yet sensitive) situations that arise in teaching writing. The scenarios vary from suspected plagiarism to responding to content/accuracy to dealing with disruptive students and more.

Narrative text is one of genre which is taught at the eighth-grade students. Anderson and Anderson stated that narratives are usually told by a story teller. Another definition, Clouse defined the narrative text is a kind of story either fictive or real which contains a series of events in which how the story is told and how the context is presented as aspects of the story construction. It should tell about an event or audience would find engaging. We might even think of our narrative as a movie in which the audience see people in action and hear them speak. Therefore, it should be detailed and clear, with event arranged in the order in some other effective way. Narrative text is one of the genres taught for the eighth and ninth grade students at Junior High School, a narrative text is a text, which relates a series of logically, and chronologically related events that are caused or experienced by factors., furthermore, states that a key to comprehending a narrative is a sense of plot, of theme, of characters, and of events, and of how they relate.

From the definition above, it said that narrative text is a story tells us about something interesting that has purpose to amuse and to entertain for the readers or viewers. We used narrative when we tell a friend about something interesting that happen to us at work or at school and we tell someone a joke.

When the researcher talks about microand macro skills, it is about assisting teachers to define the most appropriate criterion to assess students. Micro skills will be dealing with imitative and intensive writing. Meanwhile, Macro skills will be most appropriate for mastering responsive and extensive writing.

Brown explains the terms of imitative, intensive, responsive, and extensive writing. In imitative writing, students must gain fundamental sub skills. Words, punctuation, sentences, and spelling belong to those fundamental skills. In this stage, form is the main focus, while meaning and context are the secondary ones. Intensive writing is not too different from imitative one. In this stage, students start to include other sub skills like vocabulary based on a context, collocations and 
idioms, and correct grammatical features within a sentence. Students will still focus on form but meaning and context have already been concerned. The next stage is responsive writing. Students start to involve discourse level. They are trying to connect sentences into a paragraph and relate the paragraph to other paragraph in sequence way. Students here have mastered the fundamental skills mentioned in the two stages before. They now will concern with the discourse that will reach the objective their writing. Focusing on the form is still mostly concerned but meaning and context are also strongly emphasized. The last writing performance is extensive writing.

Writing in Senior High School has several rules. Those rules are based on Core Competences and Basic Competences of English (Curriculum of English) for Senior High School. In this case, the curriculum that is used in SMP Pabaku Stabat refers to 2013 Curriculum. The researcher dealt with the Nineth grade students in the first semester. Core and basic competences of writing as in Indonesian English curriculum for the Nineth grade students in the first semester overs

Statistical procedures for addressing research questions involves formulating a concise statement of the hypothesis to be tested. The hypothesis to be tested is referred to as the null hypothesis (abbreviated $\mathrm{H}_{0}$ ) because it is a statement of no difference. Hypothesis testing starts with the assumption that the null hypothesis is true... that there is/are no difference(s).

Along with the null hypothesis we must also state an alternate hypothesis (abbreviated $\mathrm{H}_{\mathrm{a}}$ ). The alternate hypothesis is a statement that a difference exists. If a null hypothesis is rejected, then we tentatively accept the alternate hypothesis and conclude that there is a difference.

$\mathrm{H}_{\mathrm{a}}$ : There is affect using Planted question technique improve the grade Nineth students' writing skill of narrative text at SMP Pabaku Stabat.

$\mathrm{H}_{\mathbf{0}}$ : There is no affect of using planted question technique improve the grade Nineth students' writing skill of narrative text at SMP Pabaku Stabat.

\section{RESEARCH METHODOLOGY}

In this study, the writer chose the place for the research at SMP Pabaku Stabat. The writer chose this place because of easiness for the writer in searching the data, extensive time, opportunity. SMP Pabaku Stabat is one of the schools in Stabat, SMP Pabaku Stabat already accreditation, which is in karang Rejo Stabat.

Quantitative methods emphasize objective measurements and the statistical, mathematical, or numerical analysis of data collected through polls, questionnaires, and surveys, or by manipulating pre-existing statistical data using computational techniques. Quantitative research focuses on gathering numerical data and generalizing it across groups of people or to explain a phenomenon. There are four main types of quantitative research designs: descriptive, correlational, quasi-experimental and experimental. The differences between the four types primarily relates to the degree the researcher designs for control of the variables in the experiment. Following is a brief description of each type of quantitative research design, as well as chart comparing the approaches.

A Descriptive Design seeks to describe the current status of a variable or phenomenon. The researcher does not begin with a hypothesis, but typically develops one after the 
data is collected. Data collection is mostly observational in nature.

\section{A Correlational Design explores the} relationship between variables using statistical analyses. However, it does not look for cause and effect and therefore, is also mostly observational in terms of data collection.

A Quasi-Experimental Design (often referred to as Causal-Comparative) seeks to establish a cause-effect relationship between two or more variables. The researcher does not assign groups and does not manipulate the independent variable. Control groups are identified and exposed to the variable. Results are compared with results from groups not exposed to the variable.

Experimental Designs, often called true experimentation, use the scientific method to establish cause-effect relationship among a group of variables in a research study. Researchers try to control for all variables except the one being manipulated (the independent variable). The effects of the independent variable on the dependent variable are collected and analyzed for a relationship.

In this research study, the researcher directly participated in the research in order to solve the problems existed in the teaching and learning process of writing and to bring improvements to the students' writing skill of grade IX students' of SMP Pabaku, Stabat.

\begin{tabular}{lll} 
No. & Group & Total Samples \\
\hline 1. & Experimental Group & 30 \\
\hline 2. & Control Group & 30 \\
\hline & Total & $\mathbf{6 0}$ \\
& Tests was be administered to obtain
\end{tabular}
data. The tests were be in the form of guided writing. The writer administers the test in two periods, namely, pre-test and post test. The materials of the tests are related to the aspects of writing skill. After analyzing the result of Pre-test, the writer found the weaknesses and strength of the implementation of teaching writing. Then, post test results were used to know the students' progress in writing.

This research consists of quantitative data collection. The quantitative data was in the form of scores that was collected from the pretest and the post test. The data was collected from some techniques used. Those techniques used was described as follows:

a. Pre-test

The pre-test is a test which is conducted before the treatment. It gave information about the students' writing scores before the treatments.

b. Treatment

In experiments, a treatment is something that researchers administer to experimental units. For example, a corn field is divided into four, each part is 'treated' with a different fertiliser to see which produces the most corn; a teacher practices different teaching methods on different groups in her class to see which fields the best results; a doctor treats a patient with a skin condition with different creams to see which is most effective. Treatments are administered to experimental units by 'level', where level implies amount or magnitude. For example, if the experimental units are given $5 \mathrm{mg}, 10 \mathrm{mg}$, $15 \mathrm{mg}$ of a medication, those amounts would be three levels of the treatment.

c. Post-test

The post-test is to measure the students' writing scores after the treatments. Both tests measured how the treatments affect the students' writing skill.

In writing, the assesment aspect of writing have some points in common with the aspect of the writing. Language structure is one 
of criteria that could be attention because in interpreting result, it could be appropiate with language structure. Because of that, the writer analyzes students' writing. There are so many method are suggested like historic scoring, primary trait scoring and analytical scoring. The writer decided to use analytical scoring which considered best evaluation of learning six major elements in writing an analytical scoring scaled that specified five major categories and description of five different levels in each category. Since the major activity of this research was Students Facilitator and Explaining Technique, the scoring system was as stated by Brown. The following was the formula:

$$
t=\frac{\bar{x}_{1}-\bar{x}_{2}}{\sqrt{\left[\frac{x_{1}{ }^{2}+x_{2}{ }^{2}}{n_{1}+n_{2}-2}\right]\left[\frac{1}{n_{1}}+\frac{1}{n_{2}}\right]}}
$$

\section{RESULT AND DISCUSSION}

The following was tables of scores taken from the result of writing test given to experimental and control groups. The test was given before and after the teaching activity, pre-test and post-test. The results were as below.

From the data above, there was an increasing score gained from post-test compared with the pre-test score from 1995 into 2245 .

From the data above, there was an increasing score gained from post-test compared with the pre-test score, from 2070 into 2175 .

Having scored and listed the scores and tables, then the finding data were simplified as the following:

$\begin{array}{lll}\mathrm{X} 1 & = & 8,33 \\ \mathrm{X} 2 & = & 3,5 \\ \mathrm{X}_{1}{ }^{2} & = & 246,91 \\ \mathrm{X}_{2}{ }^{2} & = & 207,89\end{array}$

$\mathrm{n} 1=30$

$\mathrm{n} 2=30$

To analyze the data gained from the test, the writer used the t-test formula as the following:

$$
t=\frac{\bar{x}_{1}-\bar{x}_{2}}{\sqrt{\left[\frac{x_{1}{ }^{2}+x_{2}{ }^{2}}{n_{1}+n_{2}-2}\right]\left[\frac{1}{n_{1}}+\frac{1}{n_{2}}\right]}}
$$

The resultof the t-test calculation is as shown below:

$$
\begin{gathered}
t=\frac{8,33-3,5}{\sqrt{\left[\frac{246,91+207,89}{30+30-2}\right]\left[\frac{1}{30}+\frac{1}{30}\right]}} \\
t=\frac{4,83}{\sqrt{\left[\frac{454,8}{58}\right]-[0.07]}} \\
t=\frac{4,83}{\sqrt{7,84 x 0,07}} \\
t=\frac{4,83}{\sqrt{0,54}} \\
t=\frac{4,83}{0,74} \\
t=\mathbf{6 . 5 3}
\end{gathered}
$$

From the calculating of data analysis by using t-test it is got that the value of t-observed is $\mathbf{6 , 5 3}$. Then to see whether the hypothesis of this study is accepted or not, the value is compared with the value from t-table of distribution with $d f=58$ (since there is 30 students in each group, therefore degree of freedom is $\left(\mathrm{n}_{1}+\mathrm{n}_{2}-2=30+30-2=58\right)$. Because there is $d f 58$ in table, so the writer decides to use $d f 58$ since it is closer to 70 than $d f 120$. The table at $d f$ of 58 shows that the value of $\mathrm{t}$-table $\left(\mathrm{t}_{\mathrm{t}}\right.$ is 1,67 for $5 \%$ and 2,39 for $1 \%$.

Theorytically, the alternative hypothesis (Ha) is accepted if the value of t-observed is greater than the value of $t$-table $\left(t_{o b s}>t_{t a b}\right)$. The finding above shows that t-observed is greater 
than t-table $(6,53>2,00$ and 2,66). It means that the hypothesis $(\mathrm{Ha})$ is accepted.

The result of the study proves that there is an effect of planted Question technique on students' ability in writing narrative text of Nineth grade of SMP Pabaku Stabat in academic year 2018/2019.

\section{CONCLUSION SUGGESTION}

\section{Conclusion}

Based on the result of the analysis in the previous chapter, it can be concluded that the alternative hypothesis $\left(\mathrm{H}_{\mathrm{a}}\right)$ is accepted and the null hypothesis is rejected $\left(\mathrm{H}_{0}\right)$. The result of $\mathrm{t}-$ observed is greater than the value of t-table $\left(\mathrm{t}_{\mathrm{obs}}\right.$ $\left.>t_{t a b}\right)$. The finding above shows that $t$-observed is greater than t-table $(6,53>2,00$ and 2,66). It means that there is effect of applying planted question technique on students' achievement in writing narrative text. Based on the result, it can be drawn the conclusion that teaching writing narrative text can be taught using planted question technique.

\section{Suggestion}

Based on the data prescribed previously, the writer gives some suggestions as follows.

\section{Suggestion for the students}

Students should learn other components or narrative text such as; language features and generic structures since the students' comprehending of these components influence the students' achievement of learning in writing a narrative text. Students should be firstly taught the use of past tense before they are taught how to write a narrative text.

\section{Suggestion for the teachers}

Teacher should use technique that minimize students' problem in writing. The technique suggested should brings students fun and encourage students to write easier. Planted Question technique is one of the techniques suggested in helping students to write easier and fun. In writing narrative text, students use this kind of visual technique in exploring ideas in mind until it become a good piece of writing.

\section{REFERENCES}

Babbie, Earl R. The Practice of Social Research. 12th ed. Belmont, CA: Wadsworth Cengage, 2010; Muijs, Daniel. Doing Quantitative Research in Education with SPSS. 2nd edition. London: SAGE Publications, 2010

Barbara Fine Clouse, Patterns for a Purpose: A Rhetorical Reader $3^{\text {rd }}$ edition, (NewYork: The McGraw-Hill, 2003)

Bernard, H. R., \& Bernard, H. R. (2012). Social research methods: Qualitative and quantitative approaches. Sage.

Brown, Teaching ESL Writing in Vietnam: Problems and Solutions - A Discussion from the Outlook of Applied Linguistics, VNU Journal of Science, Foreign Languages 25, 2009

Creswell, J. W. (2013). Research design: Qualitative, quantitative, and mixed methods approach

Gall, M. D., Borg, W. R., \& Gall, J. P. (1996). Educational research: An introduction. Longman Publishing.

Hamer, Methodology in Language Teaching, (NewYork: Cambridge University Press, 2002) 
Hyland, The Learning and Teaching of Reading and Writing, (Chichester: Whurr Publisher Limited, 2004)

Kementrian Pendidikan dan Kebudayaan, Kurikulum KTSP: Standar KompetensiSekolah Menengah atas (SMA)/ (Jakarta: Kementrian Kependidikan dan Kebudayaan, 2006),

Mark and Kathy Anderson, Text Types in English 2, (Melbourne: Macmillan, 1997)

Mark Anderson and Kathy Anderson, Text Types in English 3, (Melbourne: Macmillan, 1998),
Mark Warschauer, Invited Commentary: New Tools for Teaching Writing, Language Learning \& Technology 14, 2010

Neuman, W. L., \& Neuman, W. L. (2006). Social research methods: Qualitative and quantitative approaches.

Nguyen Ho Hoang Thuy, Teaching EFL Writing in Vietnam: Problems and Solutions - A Discussion from the Outlook of Applied Linguistics, VNU Journal of Science, Foreign Languages 25, 2009

Peter Westwood, What Teachers Need to Know about Reading and Writing Diffiulties, (Camberwell: Acer Press, 2008) 